\title{
Work-Based Learning: A Learning Strategy in support of the Myanmar Education Framework
}

\begin{tabular}{|c|c|}
\hline ARTICLE INFO & ABSTRACT \\
\hline $\begin{array}{l}\text { Article History: } \\
\text { Received } 11.12 .2020 \\
\text { Received in revised form } \\
03.08 .2021 \\
\text { Accepted } \\
\text { Available online } 01.01 .2022\end{array}$ & $\begin{array}{l}\text { In Myanmar, the main issue of educational field is disjunction of classroom lectures and industrial } \\
\text { practices. The students never know how to apply their theoretical skills in real workplaces. Based on } \\
\text { this issue, this paper proposed a toolkit called Work-Based Learning (WBL) for Myanmar students. } \\
\text { In 2017, our university, University of Technology (Yatanarpon Cyber City), UTYCC, introduced WBL } \\
\text { toolkit to facilitators and students. Facilitators used WBL continuum step by step to train the students } \\
\text { who utilized these steps inside or outside of the classroom. The university defined rules and } \\
\text { regulations relating with WBL activities such as credit combination to final result, holding } \\
\text { curriculum revise and review meeting by inviting industries, project shows by connection with } \\
\text { industrial needs. After running WBL activities for three years, there are many handout forms for } \\
\text { facilitators, learners and industries which are used in this paper in analyzing toolkit's results. This } \\
\text { paper discusses about those analytical results of applying WBL toolkit in university level consist of } \\
\text { facilitators, students and industries in details. }\end{array}$ \\
\hline
\end{tabular}

(C)TUARA Journal. All rights reserved

Keywords:

WBL, theoretical skills, real workplaces, facilitators, learners, industries

\section{INTRODUCTION}

For countries of lower Mekong region (Myanmar, Vietnam, Cambodia, Laos, Thailand), USAID COMET guides how to develop the educational sectors of each country. There are twelve universities of above counties which participated in this MS2W network (Mekong Skills to Work). There are many toolkits to apply for developing stages of hands-on practice in classroom activities. The former and valuable toolkit is work readiness skills which compose of six essential skills. The toolkit is target to facilitators for combining with their classroom lectures (Darche, et al., 2009). Diligence, one of six work readiness skills, takes initiative in essential toolkits which guides the students to take responsible for their own work and train to know how to work under and respect supervision. In collaboration, the second one, facilitators can define the ground rules of a team. The students can work with others to achieve individual or group goals from this skill. Another skill, adaptability, is a skill which trains the students to accept the problems and change and solve these as they arise. The fourth skill is communication that the students must communicate clearly and gets along with others for a range of purposes. The most challenge for Myanmar facilitators and students is time management skill. Most of the Myanmar citizens do not know how important this skill is important in real workplace. In this era, our country opens international trade and most of the transnational corporations give the labors and resources from many different countries' chances to Myanmar citizens. In our field, science and technology, Japan IT companies are famous for students' job opportunities. Most of our students are recruited by these companies and the survey from these companies shows that Myanmar students are lack of time management skill. The facilitators should define the restricted rules for students' project deadline or the assignment deadline in classroom activities for their time management skill. The final skill is problem solving which is also important for students. The facilitators can retrieve the students' innovative ideas by applying projectoriented learning in classroom (Atkinson, 2016).

Above mentioned skills are key factors for linkage of students' theoretical knowledge and industrial practices. The facilitators can train the students to achieve work readiness skills from classroom activities. However, these are not enough for the real workplace. Work-based learning (WBL) is the main character for students who need to work under pressure of real workplace for their real work experiences. The linkage of key factors is shown in figure 1 (Ball \& Manwaring, 2010). 


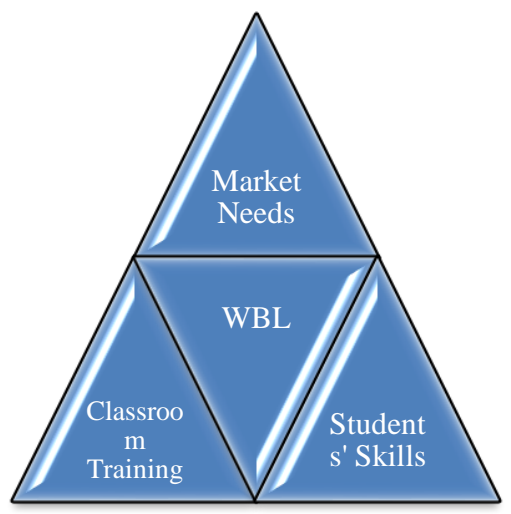

Figure 1. WBL Balance Triangle

\section{WORK-BASED LEARNING (WBL)}

Work-Based Learning (WBL) is an educational strategy that provides students with the opportunity to put theory into practice with real-life work experiences. This can range from internships to job shadowing, simulations or mentorship programs. WBL gives students the opportunity to explore what they have learned in the classroom within a real-world context. Not only is this immensely beneficial for hands-on learners, but it also gives students some much-needed direction, and it gets them thinking about what they want to do after graduation (Haruna, et al., 2019).

This approach to education proves highly effective for recruiting processes at top firms and companies. When students can prove that they have exposure to the working world, employers are able to see them as mature candidates who are prepared to face the diverse challenges of today's workplace.

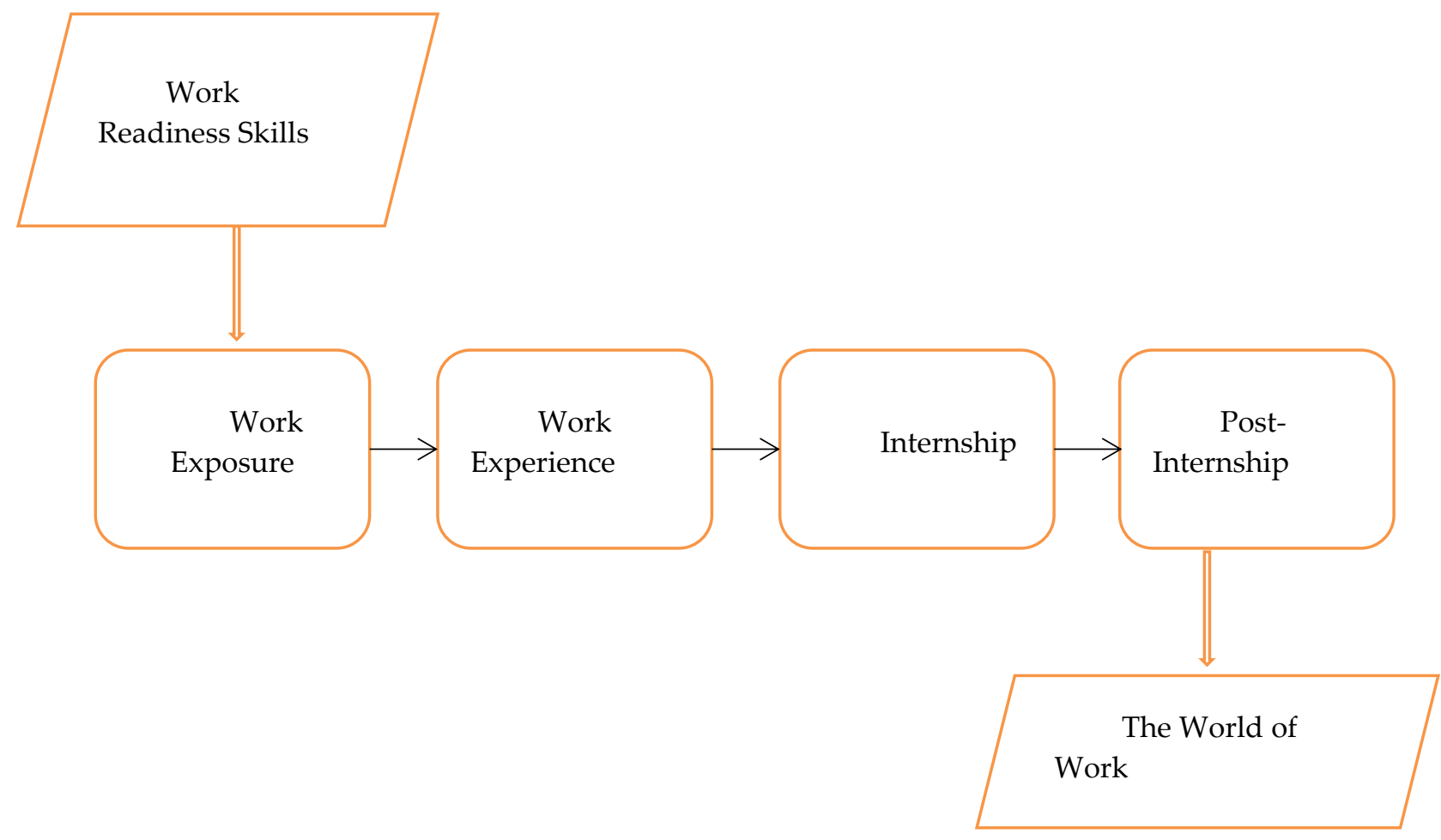

Figure 2. WBL Continuum (MS2W, 2017)

As in figure 2, Work-Based Learning is a bridge which fills the gap between education and the working world. Although theory is important for any university-level education, an overemphasis on theory can make it hard for students to ground their knowledge in something tangible that will result in a career and unsure of 
what direction is best after graduation if they don't know about the workplace during students' life. To avoid this problem, WBL toolkit is used as university-level education. There are four steps in WBL toolkit to forward to the real workplace which will discuss in further sections. The main fact of this toolkit is balance of facilitators, learners and employers. There are many standard forms for each WBL activity and it composes of four, six and eight standard forms for employers, facilitators and learners, respectively.

UTYCC's facilitators and learners applied step by step of WBL continuum in their classrooms. The university collaborated with industries in implementing WBL and university's WBL coordinator trained many facilitators from computer and technological universities. As mentioned earlier, WBL is based on practical usage of students' theoretical skills in industries. In Myanmar, Art and Science universities fail to apply WBL in case of their weakness in linking with industries. Moreover, some WBL activities are not compatible with Myanmar industrial culture in which the employers are afraid to teach the students in short term basic.

This paper point out how each WBL activity works, which handouts do the facilitators, learners, employers use in what situation and their analytical results. Those analytical results are taken from facilitators, learners and employers' handouts and google survey forms (Oliver, et al., 2014).

\section{Work Exposure}

As work exposure is the first step of work-based learning activities, a student or a group of students can do this activity in their daily life easily. The key factor of work exposure activity is "Observed" which means the students can observe the real workplaces with their eyes. There are three types of work exposure activities "work observation, informational interview and one-day job shadowing". As mentioned earlier, the students need only their eyes for work observation. However, the students can ask about workplace situation if they get chance.

Work Observation.To do work observation, the students do not need any permission because they just look and observe the work place and fill the forms as they have seen. Sample questions are as follow.

What do you observe about how they dress?

What do you observe about how they treat customers?

What do you think about their working conditions?

What skill do you think they need to do this job?

Work observation is the easiest one in WBL activities in which the students do not need to concern about industrial type, employers and employees working situations, place, time, security and so on. They just need to observe the workplace as a customer or outside of the workplace.

Informational Interview. For the informational interview, the students need to ask the following questions to someone of workplace.

Have you worked here long, how long?

Is this your first job? Why did you choose it?

What prepared you for this job?

Where did you get those skills to get this job?

How many hours do you work?

Informational interview is a little difference from work observation. Students are eager to do interveiw as a group rather than alone. The students can do informational interview if and only if they have chance to do so because some employers or employees are not willing to answer students' questions because of working situation. The students need to carry their student ID card to do this activity. If the students do not have chance to do interview, they can use work observation technique.

Job Shadowing.The students should try this approach, one day job shadowing, if they are familiar with the workplace. Most of the industries may deny for job shadowing with many reasons such as they are busy; there is no enough to supervise the students; they value the privacy and so on. In Myanmar, most of the private industries do not accept one day job shadowing for students. However, the government corporations accept this type of activity for students' group with supervisors from university. The students can ask following sample questions in one day job shadowing process. 
What type of education and training would you recommend for someone starting out in this career?

Is there a possibility for further career advancement?

Can you describe a typical day at work?

What is the most challenging/difficult part of your job?

What does your employer look for in young job seekers?

The facilitators began with two types of work exposure activities (work observation, informational interview) in their classrooms at UTYCC. Three facilitators tried in three ranking classrooms which have class size at 52 as shown in figure 3.

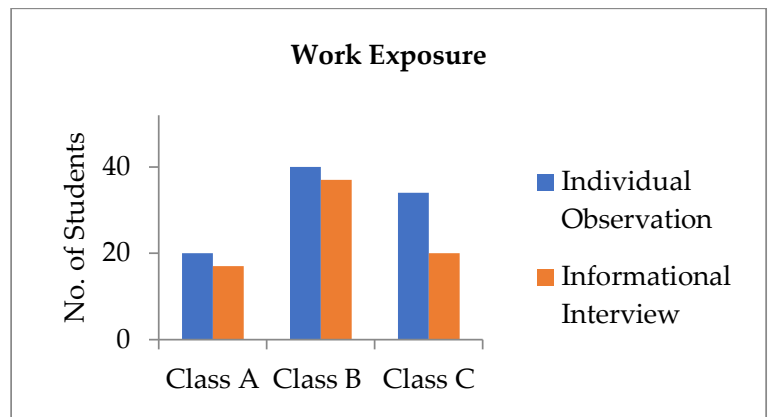

Figure 3. Individual Work Exposure Activities by UTYCC Students

After doing these two activities, facilitators took the google survey form for deteming students' feeling in doing work exposur. After analyzing of the survey forms, the students from class A are afraid to do these activities alone while they all are good at team work. Class B students are very interesting in this kind of activities. $10 \%$ of students can find out their career ways after these activities. Although most of class C students are also interested to do these activities, they are willing to go out from the classroom actually.

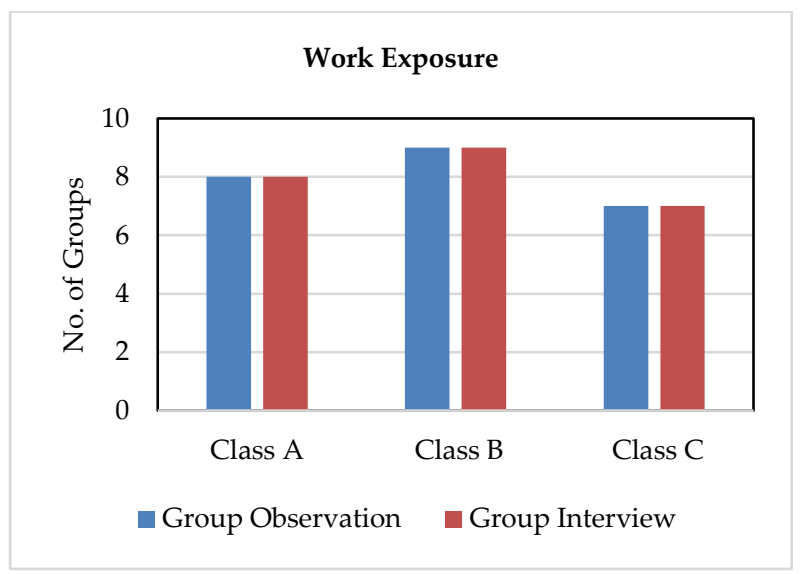

\section{Figure 4.Group Work Exposure Activities by UTYCC Students}

After examining figure 3 and 4, the middle rank students are most suitable to try with work exposure activities while high rank and low rank students are thinking about specific field whether they do not like or not as their guardians told them. This phenomenon is mostly found in Asia countries. As mentioned earlier, one day job shadowing is not possible for Myanmar students because of the restrictions of industries.

However, the students can go industrial visit with their respective facilitators as a job shadowing activity. There are two kinds of workplace for field trip: matched with students' specialized field and non-matched with their respective majors. If the students visit to non-matched industries, they can just observe and attend the seminar held by industries. If they go to matched industries, they can ask the related questions and may get the knowledge for the future career choices.In UTYCC, the third and fouth year students must go field trip where rector or faculty heads must negotiate with government corporations first before field trip in which indistrial administrators assign companies of industrial zone for accepting students' visit and explore. In figure 5, estimating about 200 students for each major go field trip every year (senior students mean fouth year students, junior students mean third year students). The students must bring two things on field trip: survey 
form and field trip book in which students ask the questions about workplace and write down the answers and company's incharge must sign in the book.

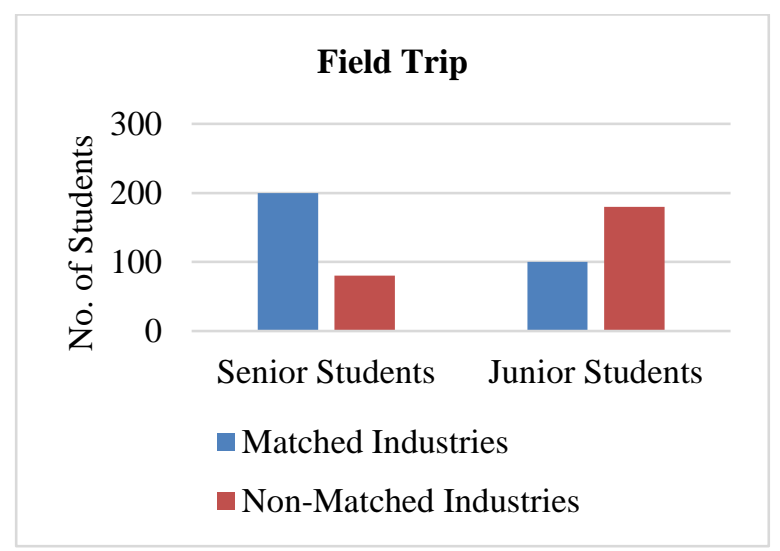

\section{Figure 5. Yearly Major Field Trip done by UTYCC Students}

Another essential fact of work exposure is it is possible if the students' observation area is not related with their specialized fields because this activity only aims to get the answer of "What is Work?" question. Thus, students are exploring more non-matched industries at their junior class and more matched industries in next year. The secret of potential success in work exposure activities is the students can do these kinds of activities as daily basis. Moreover, the facilitators can instruct the students to do these activities by giving them credits or marks combing with their classroom activities (ETF \& Ercan, 2014). Normally, the facilitators can do these activities twice a semester with their students.

\section{Work Experience}

The second step, work experience is the challenge one for the facilitators. In contract with work exposure, this activity is not easy and cannot do as a classroom activity. Both facilitators and learners should take time for work experience activity.

As continuum, the students need to stay at least five or more days to get the work experience. The main keyword of work experience activity is "touching and doing". Work experience provides the following opportunities for learners (Sweet, 2013).

- $\quad$ Sample different workplaces to make informed career choices

- $\quad$ Practice both technical and work readiness skills through learning by doing actual work

- $\quad$ Identify an appropriate workplace to apply for an internship

In Myanmar, most of the industries usually deny to accept the students for a few days. However, they allow the students at least one month for work experience. Therefore, the students need to use their holidays to achieve work experience. The different factor of work experience from work exposure is that this activity needs the university or faculty permissions. The employers want to see the official letter from the students with the signature of a professor with the seal of faculty or university. Therefore, the facilitators have the extra work for preparing official letter for each student while some students group together for this activity.

UTYCC sends the junior students for their work experience to unrelated field of their study. Some IT students go to gas shop and private school and they are paid by the employers. The students looks for the workplace themselves to achieve work experience. The facilitators gives the permission letter to workplaces and both survey forms and work-experience handouts to students with thier signature. The analytical results of figure 6 are calculated based on these survey forms. 


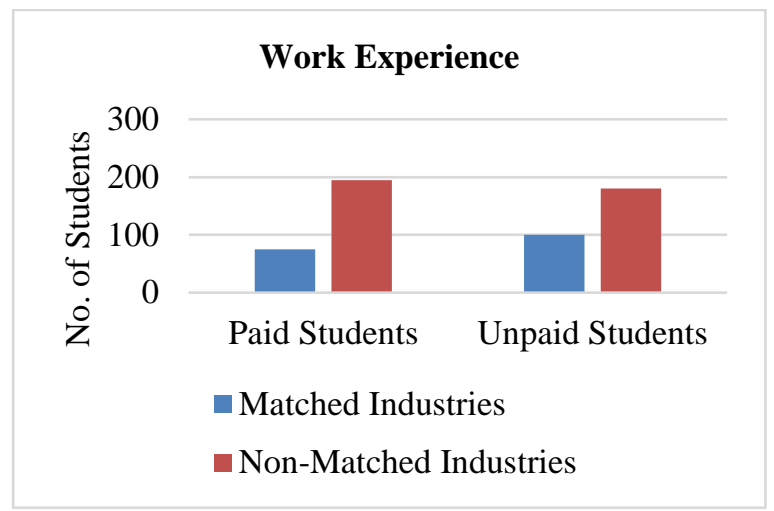

Figure 6. Work Experience Activities by UTYCC Students

There are three parts in work experience form where the students need to fill this form as daily routine. The learner information is the first part while the industry information takes place as the second one. The most essential part of work experience section is the third one which contains the daily works. The learners must report which activities and tasks they finished, which new knowledge and skills they learned and which tools, machinery, and equipment they used daily. Their supervisors must check these facts are right or wrong weekly, confirm some facts and sign the report. Moreover, the supervisors must contact university WBL coordinators and consult the students' conditions.

The difficult reason to do the work experience is that the industry staffs are confused to cooperate with academic culture in Myanmar. They deny the students with many reasons like that they are afraid to accept the strangers in a short time, they have no supervisors to train the students, and they have no time to report and so on. After running WBL for three years in UTYCC, the students are accepted for work experience if they did the work exposure activities at the same place.

\section{Internship Program}

Most of the ASEAN universities are familiar with the internship program which has been developed for many years. However, the students have been found many difficulties in internship program. The reason is that the institutes never introduce about the real workplace in the classroom training. The main message of WBL is to get to the internship point through many steps such as developing work readiness skills in classroom, work exposure activities and finding work experience in short-term purpose.

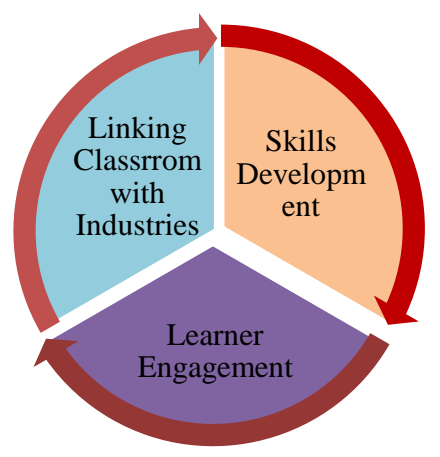

Figure 7. Key factors of Internship Program (Thomas, 2012)

In Myanmar, the internship program was started from 2017 as a whole country. The Ministry of Education, itself, directed to complete an internship policy at least eight weeks for bachelor program. As consequences, each student found their real abilities and actural interests by staying and learining in workplace as defined internship timeline. The official letter, logbook for evaluation and credit system are required to define by university. UTYCC initiates the logbook and other forms for WBL activities which are printed the whole country. These are now useful in many technological and computer universities as standard forms. Like work experience activity, the students need to fill their daily works and the supervisors need to 
check them and sign them during eight weeks. Both the students and supervisors from industries and university must take the survey after internship program.

In UTYCC, the fifth-year students work as interns in April and May, October, November before they become final year students. After running internship program for three years, even in 2020, most of the students know about the real workplace, the challenges and can also distinguish which works are matched with their skills.

\section{Post Internship Program}

Despite the fact that this section is with the title of post internship, this fourth step is demanded to accomplish after each step of WBL activities. It means that the students are required to update their CV after each WBL activity such as individual or group observation, informational interview, work experience and internship. After the internship program, the students must refinetheir skills. MS2W network uses YouRock in updating $\mathrm{CV}$; the sample diamond shape of skills development can be found in figure 8 .

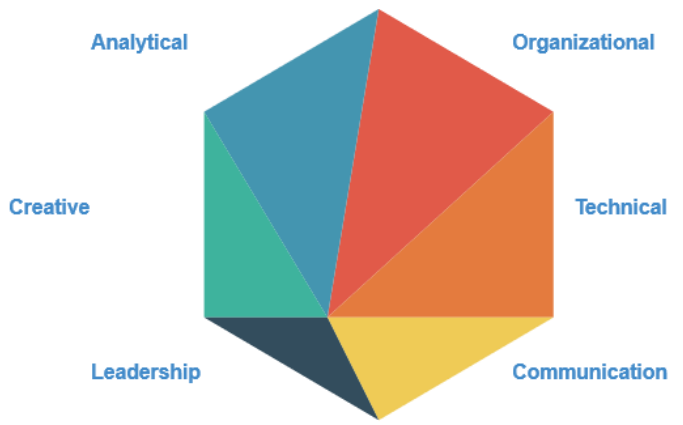

\section{Figure 8. YouRock Skills Development Diamond of a Student}

There are six skills in the diamond such as analytical, creative, leadership, organizational, technical and communication. For instance, if a student operates as a volunteer at a local community organization, the student's skills are refined by organizational and communication sectors. This diamond helps the students to monitor their skills for continuous development and their employer can comprehend their skills in one shape.

Another post-internship activity is presentation where the students from same internship companies must prepare their final presentation (Linehan, 2008). All the teachers from each department must attend these seminars and discuss about how to upgrade internship program next year. During presentation, the following topics must be coverage.

- What they got?

- What they would like to keep learning?

- Company's Nature?

- Suggestions for university?

- Needs and problems?

In addition, seniors students also make seminars for sharing their experiences about internship such as travelling cost, weather, living cost, pros and cons of companies for young students. Later, students create "Internship" app for the whole university where students can find companies based on their interested field, their skills, allowance, city, etc.

\section{Applying Wbl in Myanmar and Cambodia}

About forty teachers of University of Computer Studies (Taungoo), UCS (Taungoo), were trained by WBL coordinator in 2017. In subsequent year, twenty five teachers from UTYCC and twenty teachers from USEA (University of South East Asia), Cambodia are trained to conduct WBL activities in their classroom. In 2019, 40 teachers (20 from Computer universities and 20 from Technological universities) are trained by WBL coordinator at UTYCC. Generally, five universites replied about WBL application in their classroom with evidences. 


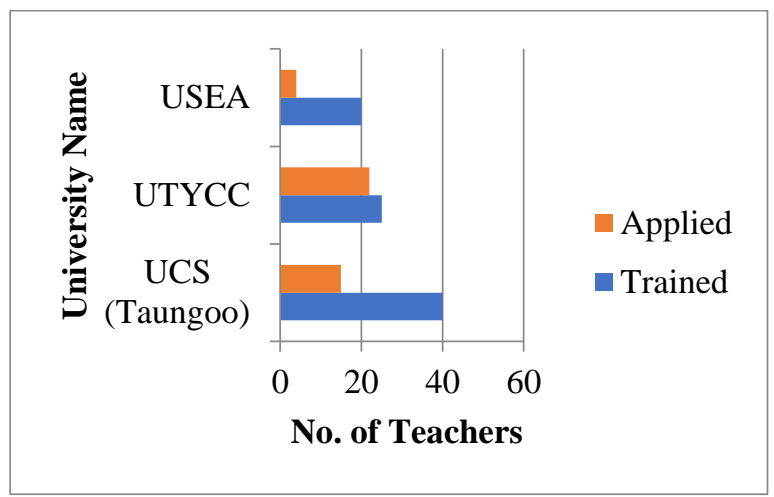

Figure 9. Applying WBL in MS2W Network

As shown in above figure, there are many teachers in training UCS (Taungoo). However, only $37 \%$ was using this technique in the classroom. In UTYCC, the work-based learning technique is successful almost $90 \%$ which is guided by WBL coordinator. In USEA, merely $2 \%$ teachers applied WBL because of its location. This university is situated in Siem Reap which has many part time jobs for the students. The teachers and students are not interested to do work exposure and work experience as a classwork. Although they acquire work experience from those part time jobs, they also deny to do internship which are matched with their majors. The main problem of USEA is that most of their students never choose their major as their career choice. Their priority of career choice is salary. To avoid this problem, the USEA need to push their students to go step by step of WBL continuum to reach the real world of work.

In 2019, the WBL activities are spread out to University of Computer Studies (Mandalay) and others forty technological and computer universities in Myanmar. Now some of the teachers of these universities are using WBL toolkit in their classroom training.

The result of successful WBL is as shown in figure 10 which contains three universities applying WBL toolkit.

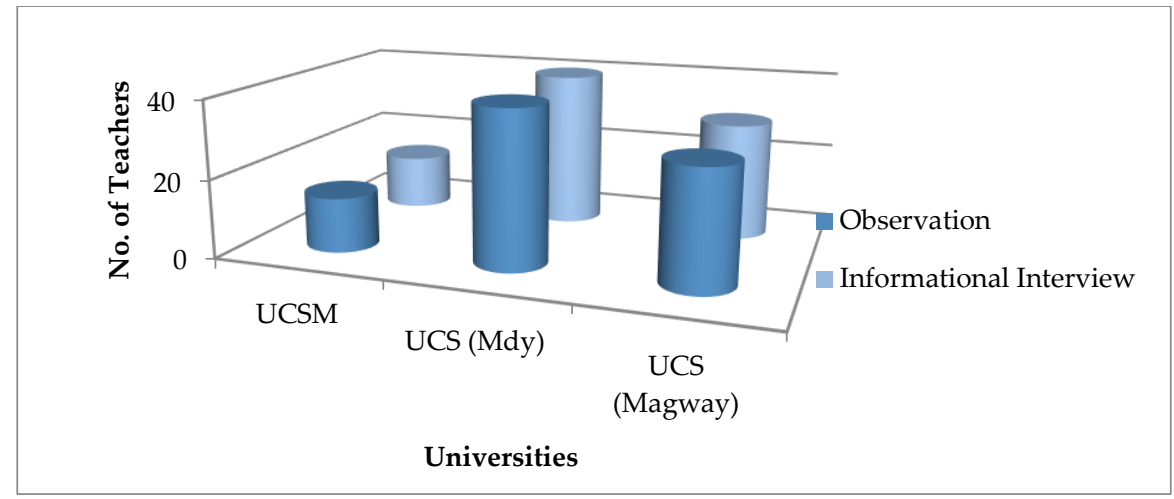

Figure 10. Applying Work Exposure Activities in Three Universities

\section{RESULT, DISCUSSION AND SUGGESTIONS}

In this paper, the meaning of WBL, the usage of WBL and the survey of applying WBL toolkit for UTYCC students majoring in Information Science and Technology in the classroom training have been discussed with the various points of view. During three years, the career choice of Myanmar students is changed based on their real-world workplace experience. Most of the students cannot decide themselves how their skills are useful in workplace before 2017. After applying WBL in Myanmar and other Mekong regions, the balance of triangle (the facilitators, the students and the industries) can be controlled equally. The university also needs to hold industrial partnership meeting for revising curriculum matched with industrial needs (Duman \& Karagoz,2016 \& Karagoz, \& Ruzgar, 2020). 
The conclusions obtained in the research conducted for the purpose of examining the usage of WBL in Myanmar education framework can be summarized as follows:

1) Work exposure activities are the most popular one between students who are willing to do more individual observation than group observation and more group informational interview than individual interview alone while one-day job shadowing is not appropriate with Myanmar industries' culture.

2) Work experience is less favorite one in Myanmar because it takes too long staying in workplace during their holidays and most industries refuse to accept the students as short-term basis.

3) Internship is the long-term program for students provided by related industries with their majors. Both mentors from university and supervisors from industry are very important to guide students' career choice in this process. While prior two activities (work exposure, work experience) are targeted to answer the question "What is work?" this internship process aims to introduce their future workplace and help the students to find their future career choices. The students can update their skills and resume after internship program as a post internship process.

4) In training process for Myanmar universities, about 60\% from UCS (Taungoo), 30\% from UCS (Magway), 30\% from UCS (Mandalay), 20\% from UCSM (University of Computer Studies (Mandalay)), 10\% from MTU (Mandalay Technological University), 15\% from UCSY (University of Computer Studies (Yangon)) students are conducted WBL activities although TOT success rate is 15\%.

5) The important fact of WBL continuum is to go through step by step. The students must be trained in classroom along with work readiness skills and then introduced about "work" and "workplace" and finally guided about their career choices.

\section{Suggestions}

According to the conclusions of the research, Myanmar students have the knowledge what they want to do, which skills they have and how to apply them. Myanmar can reduce unemployment rate and number of unskillful workers by linking local industries' needs and students' skills (Oam, 2017).

However, there are many difficulties in applying WBL in Myanmar because there are part time jobs in industries rarely. There are many reasons why industries refuse the students such as they do not trust new people, they are worry about security concerns, and they have no supervisors to guide the students and so on. WBL coordinator needs to push not only students but also industries to implement WBL.

WBL coordinator also needs to connect global industries and make long-term contracts for students' internship opportunities. Moreover, university must define accurate rules and regulations for each WBL activity. Departments must arrange the students in performing WBL such as official letters and announcements for both students and industries; get around with government industrial zone and nongovernment organizations.

Facilitators must centralize about "What is work?" questions for junior students and convene job opportunities for senior students. Students must also show their hard skills and soft skills in workplace to attract workplaces' first impression. WBL coordinator must handle all the surveys from facilitators, learners, employers and take action for all complaints.

\section{ACKNOWLEDGEMENT}

Firstly, I would like to appreciate Dr. Aung Win, Rector, and Administrator of Mekong Skills2Work Network project supported by USAID COMET for his leadership and give me the chance to do this project. And then, I wish to express my deepest gratitude to my colleagues Prof. Dr. Reenu, Prof. Dr. Hninn Aye Thant, Dr. Htin Kyaw Oo, U Thet Zaw Aye for believing me to work together for this long-term project. I also thank USAID team for choosing our university, University of Technology (Yatanarpon Cyber City), with all respects to promote the education system of Myanmar. I am also grateful to my supervisor, Mr. Chris Murray, Senior International Technical Advisor,for his patent and kindly resolve my problems. Last but not least, many thanks are extended to all persons who directly and indirectly contributed towards the success of applying WBL toolkit in Myanmar.

\section{REFERENCES}


Atkinson, G. (2016). National center for vocational education research. Work-based learning and work-Integrated learning: Fostering engagement with employers, ISBN: 978-19-25173-59-8.

Ball, L. \& Manwaring, G. (2010). The quality assurance agency for higher education 2010. Making it work: A guidebook exploring work-based learning, ISBN: 978-1-84979-168-7.

Darche, S., Nayar, N. \& Bracco, K. R. (2009). The james irvine foundation. Work-based learning in california.

Duman,T. \& Karagöz, S. (2016).An evaluation of Turkish teacher education system compared to other

ETF, T. \& Ercan, L. (2014). Work-based learning: A handbook for policy markers and social partners in ETF partner countries.

Haruna, R., Kamin, Y. B. \& Buntat, Y. B. (2019). IJRTE. Understanding work-based learning in technical and vocational education and training in nigeria, ISSN: 2277-3878, 8(1).

Karagöz,S. \& Rüzgar,M.E. (2020). The observations of student teachers in regard to professional qualifications of advisor teachers during teaching practicum. International Journal of Educational Research Review,5(2),141-150

Linehan, M. (2008). CIT Press 2008.Work-based learning: Graduating through the workplace, ISBN: 978-0-95457368-3.

models in different countries. International Journal of Educational Research Review,1(1),1-13.

MS2W Network (2017). Work-based learning toolkit, MS2W sourcebook: A guide for administrators and instructors.

Oam, S. B. (2017). Journal of work-applied management. work based learning: A learning strategy in support of the australian qualifications framework, 9(1), 70-82.

Oliver, D., Freeman, B., Young, C., Yu, S. \& Verma, G. (2014). Employer satisfaction survey report for the department of Information, ISBN: 978-1-74361-653-6.

Sweet, R. (2013). UNESCO-UNEVOC-Revisiting global trends in TVET. Work-based learning: Why? How? ISBN 978-92-95071-57-5.

Thomas, B. \& Angrove, M. (2012). Emerging themes in business seminar series. Promoting work based learning and capturing its outcomes. 